\title{
The Plasmid-coded Metabolism of Naphthalene and 2-Methylnaphthalene in Pseudomonas Strains: Phenotypic Changes Correlated with Structural Modification of the Plasmid pWW60-1
}

\author{
By PATRICIA A. CANE ANd PETER A. WILliAMS* \\ Department of Biochemistry and Soil Science, University College of North Wales, Bangor, \\ Gwynedd LL57 2UW, Wales, U.K.
}

(Received 8 February 1982; revised 7 May 1982)

\begin{abstract}
Pseudomonas sp. NCIB 9816 contains two plasmids: pWW60, an IncP9 plasmid of $87 \mathrm{~kb}$ encoding genes for the catabolism of naphthalene, and pWW61, a cryptic plasmid of about 65 $\mathrm{kb}$. The ability to degrade naphthalene was transferred at low frequency by conjugation from strain NCIB 9816 into a plasmid-free strain of Pseudomonas putida, PaW340. A transconjugant, PaW701, containing the naphthalene plasmid pWW60-1, metabolized naphthalene and salicylate via the ortho pathway. 2-Methylnaphthalene was not a growth substrate but was partly metabolized with accumulation of a brown compound in the medium $\left(\lambda_{\max }=440 \mathrm{~nm}\right)$. Spontaneous mutants of PaW701 with the ability to grow on 2-methylnaphthalene arose at a frequency of about $10^{-5}$. These fell into two groups. Group A mutants had no detectable salicylate hydroxylase activity and accumulated salicylate from naphthalene in culture supernatants: they appeared to grow on the pyruvate released from oxidation of the first ring of both substrates. Their plasmids all contained a $16.7 \mathrm{~kb}$ insert in different sites within a small, limited region of the plasmid. Group B mutants used a meta pathway for catabolism of naphthalene and 2-methylnaphthalene. Their plasmids had undergone a small deletion of from 1.2 to $1.6 \mathrm{~kb}$ in a region of the plasmid close to the sites of the insertions in the group A mutants.
\end{abstract}

\section{INTRODUCTION}

The biochemistry and regulation of naphthalene metabolism in Pseudomonas sp. NCIB 9816 has been the subject of conflicting reports. Davies \& Evans (1964), who first isolated the strain as Pseudomonas $\mathrm{P}_{\mathrm{G}}$ and submitted it to the National Collection of Industrial Bacteria (NCIB), showed that naphthalene was converted through salicylate to catechol (see Fig. 1) and surmised that the catechol was further metabolized by the meta pathway because of the presence of its first enzyme, catechol 2,3-dioxygenase (EC 1.13.11.2). Williams et al. (1975) confirmed this pathway with some more detailed enzymological data, and also showed that 2-methylnaphthalene was metabolized by the same sequence of reactions. However, Barnsley (1976), using a fresh culture obtained from NCIB, showed that the catechol resulting from naphthalene catabolism was assimilated by the ortho or $\beta$-ketoadipate pathway, with catechol 1,2-dioxygenase (EC 1.13.11.1) as the first enzyme, and that the catechol 2,3-dioxygenase activity was present only at low constitutive levels. Barnsley (1976) found that there were differences in the biochemistry of naphthalene catabolism between this clone and that supplied by P. A. Williams, although his results with the latter differed significantly from those previously obtained by Williams et al. (1975). In both laboratories it was assumed that there were at least two variants of this strain in existence.

\footnotetext{
Abbreviations: C12O, catechol 1,2-oxygenase; C23O, catechol 2,3-oxygenase; HMSD, 2-hydroxymuconic semialdehyde dehydrogenase; HMSH, 2-hydroxymuconic semialdehyde hydrolase; MLE, cis,cis-muconate lactonizing enzyme; $\mathrm{SH}$, salicylate hydrolase.
} 
1<smiles>[R]c1ccc2ccccc2c1</smiles>

2<smiles>[R]c1ccc2c(I)ccc(CCC(=O)O)c2c1O</smiles>

5<smiles>O=C(O)/C=C\C=C/C(=O)O</smiles><smiles>[R]C(=C)/C=C\C=[W]</smiles>

SH

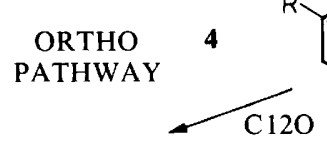<smiles>O=C(O)CC1C=CC(=O)O1</smiles>

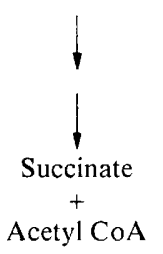

META

PATHWAY<smiles>[13CH3][134CH3]</smiles>



HMSH<smiles></smiles>

Fig. 1. The pathways for metabolism of naphthalene $(\mathrm{R}=\mathrm{H})$ and 2-methylnaphthalene $\left(\mathrm{R}=\mathrm{CH}_{3}\right)$ Compounds shown are (2-methylnaphthalene metabolites in brackets): 1, naphthalene (2-methylnaphthalene); 2, 1,2-dihydroxynaphthalene (1,2-dihydroxy-7-methylnaphthalene); 3, salicylate (4methylsalicylate); 4, catechol (4-methylcatechol); 5, cis,cis-muconate; 6, muconolactone; 7, 2hydroxymuconic semialdehyde (2-hydroxy-5-methylmuconic semialdehyde); 8, 4-oxalocrotonate (2methyl-4-oxalocrotonate); 9, 2-oxopent-4-enoate (2-oxohex-4-enoate). Acetaldehyde and propionaldehyde are (with pyruvate) the final products of naphthalene and 2-methylnaphthalene respectively. The enzymes assayed are denoted by their abbreviations.

We have been prompted to reinvestigate naphthalene assimilation in Pseudomonas sp. NCIB 9816 for two reasons. Firstly, a number of reports have indicated that plasmids are invariably responsible for naphthalene catabolism in Pseudomonas spp. (Dunn \& Gunsalus, 1973; Boronin et al., 1977; Boronin et al., 1980). Secondly, we have found a number of instances where the phenotype of strains carrying catabolic plasmids can alter spontaneously as a result of modifications in the plasmid DNA structure (Bayley et al., 1977; Jeenes et al., 1982; Pickup \& Williams, 1982). This paper presents results on strains of Pseudomonas putida containing a catabolic plasmid, pWW60-1, derived by conjugation from strain NCIB 9816. Selection for 
growth on 2-methylnaphthalene results in two classes of mutants in which both the biochemistry of naphthalene utilization and the plasmid structures have altered.

\section{METHODS}

Bacterial strains. Details of all relevant bacterial strains, and their plasmid complements, are shown in Table 1.

Conjugation experiments. Plate matings were the only consistently successful method of transferring the plasmids used in this study. Samples $(0.1 \mathrm{ml})$ of overnight nutrient broth cultures of both donor and recipient were mixed directly on the selective agar plates. Streptomycin $\left(1 \mathrm{mg} \mathrm{ml}^{-1}\right)$ and tryptophan $\left(50 \mu \mathrm{g} \mathrm{m}^{-1}\right)$ were incorporated into selective plates for all derivatives of PaW340.

DNA extraction and digestion. Plasmid DNA was extracted by the preparative method of Wheatcroft \& Williams (1981). Restriction enzymes were purchased from Uniscience (Cambridge, U.K.) and used according to the suppliers' instructions. Digests of plasmid DNA were electrophoresed in $0.7 \%(\mathrm{w} / \mathrm{v})$ agarose gels made in running buffer containing $89 \mathrm{mM}$-Tris, $2.5 \mathrm{~mm}-\mathrm{Na}_{2}$ EDTA and $89 \mathrm{mM}-\mathrm{H}_{3} \mathrm{BO}_{3}, \mathrm{pH} 8 \cdot 2$, containing $0 \cdot 5 \mu \mathrm{g}$ ethidium bromide $\mathrm{ml}^{-1}$. Samples were run into the gel from wells at $100 \mathrm{~V}$ for $15 \mathrm{~min}$, after which they were completely submerged in running buffer (without ethidium bromide) and electrophoresed for $20 \mathrm{~h}$ at $160 \mathrm{~V}$ and $35 \mathrm{~mA}$. Gels were photographed as previously described (Wheatcroft \& Williams, 1981).

The size of fragments was calculated by comparison of their mobilities with those of fragments of pWW0 of known size (Downing \& Broda, 1980). Plasmid sizes were obtained by summation of the sizes of the fragments produced by single and/or double digestion.

Preparation of cell extracts. Cells were grown in batch culture (Williams et al., 1975) and were harvested by centrifuging at $1000 \mathrm{~g}$ for $1 \mathrm{~h}$. They were washed in $100 \mathrm{~mm}$-phosphate buffer, $\mathrm{pH} 7.5$, and stored as a pellet at $-20^{\circ} \mathrm{C}$. When required the pellet was resuspended in the appropriate buffer and sonicated at $0{ }^{\circ} \mathrm{C}$ in an MSE 100 $\mathrm{W}$ sonic disintegrator in three $60 \mathrm{~s}$ bursts. For all enzymes, except the catechol dioxygenases, extracts were made in $100 \mathrm{~mm}$-phosphate buffer, $\mathrm{pH} \mathrm{7.5}$; in extracts for assay of the catechol dioxygenases, the same buffer included $10 \%$ $(\mathrm{v} / \mathrm{v})$ acetone.

Enzyme assays. Enzymes were assayed by the following published procedures: salicylate hydroxylase (SH), Yamamoto et al. (1965); catechol 1,2-dioxygenase (C12O, EC 1.13.11.1), Hayaishi et al. (1957); catechol 2,3dioxygenase (C23O, EC 1.13.11.2), 2-hydroxymuconic semialdehyde dehydrogenase (HMSD) and 2-hydroxymuconic semialdehyde hydrolase (HMSH), Sala-Trepat et al. (1972); cis,cis-muconate lactonizing enzyme (MLE), Ornston (1966). Protein was determined by the biuret procedure.

Identification of salicylates in culture media. Culture supernatants were shaken twice with 0.5 vol. diethyl ether, and the ether extract discarded. The supernatant was then acidified with $\mathrm{HCl}$ to $0 \cdot 1 \mathrm{M}$ and the ether extraction

\section{Table 1. Strains of Pseudomonas}

\begin{tabular}{|c|c|c|c|}
\hline Strain & Relevant phenotype* & Plasmids & $\begin{array}{l}\text { Method of formation } \\
\text { or reference }\end{array}$ \\
\hline $\begin{array}{l}\text { PGB1 (Pseudomonas } \\
\text { sp. NCIB } 9816, \\
\text { wild-type) }\end{array}$ & $\mathrm{Nah}^{+} 2 \mathrm{MeNah}^{+} \mathrm{Sal}^{+} 4 \mathrm{MeSal}^{-} 5 \mathrm{MeSal}^{-}$ & pWW60, pWW61 & - \\
\hline PGB2 & $\mathrm{Nah}^{-} 2 \mathrm{MeNah}^{-} \mathrm{Sal}^{-} \mathrm{Mtol}^{+}$ & pWW61, pWW0 & $\mathrm{PaW} 15 \times \mathrm{PGB} 1 \dagger$ \\
\hline PGB3 & $\mathrm{Nah}^{-} 2 \mathrm{MeNah}^{-} \mathrm{Sal}^{-} \mathrm{Mtol}^{-}$ & pWW61 & Benzoate curing of PGB2 \\
\hline $\begin{array}{l}\text { PaW1 ( } P \text {. putida } \\
\text { mt-2, wild-type) }\end{array}$ & $\mathrm{Mtol}^{+}$ & pWW0 & $\begin{array}{l}\text { Williams \& Murray } \\
\text { (1974) }\end{array}$ \\
\hline $\mathrm{PaW} 11$ & $\mathrm{Mtol}^{-} \mathrm{Ben}^{-} \mathrm{Cat}^{-}$ & - & PaW 1, mutagenesis \\
\hline PaW 15 & $\mathrm{Mtol}^{+} \mathrm{Leu}^{-}$ & pWW0 & $\begin{array}{l}\text { Williams \& Murray } \\
\text { (1974) }\end{array}$ \\
\hline PaW85 & $\mathrm{Mtol}^{-} \mathrm{Ben}^{+} \mathrm{Cat}^{+}$ & - & Bayley et al. (1977) \\
\hline $\mathrm{PaW} 340$ & $\mathrm{Mtol}^{-} \mathrm{Ben}^{+} \mathrm{Cat}^{+} \mathrm{Trp}^{-} \mathrm{Str}^{\mathrm{r}}$ & - & PaWl, mutagenesis \\
\hline PaW701 & $\begin{array}{l}\mathrm{Nah}^{+} 2 \mathrm{MeNah}^{-} \mathrm{Sal}^{+} 4 \mathrm{MeSal}^{-} 5 \mathrm{MeSal}^{-} \\
\mathrm{Trp}^{-} \mathrm{Str}^{r}\end{array}$ & pWW60-1 & PGB1 $\times$ PaW $340 \dagger$ \\
\hline $\left.\begin{array}{l}\text { PaW711 } \\
\text { PaW721 } \\
\text { PaW722 }\end{array}\right\}$ & $\begin{array}{l}\mathrm{Nah}^{+} 2 \mathrm{MeNah}^{+} \mathrm{Sal}^{-} 4 \mathrm{MeSal}^{-} 5 \mathrm{MeSal}^{-} \\
\mathrm{Trp}^{-} \mathrm{Str}^{\mathrm{r}} \text { (group A) }\end{array}$ & $\begin{array}{l}\mathrm{pWW60-9} \\
\mathrm{pWW60}-16 \\
\mathrm{pWW60-17}\end{array}$ & $\begin{array}{l}\text { PaW701, selection for } \\
\text { growth on }\end{array}$ \\
\hline $\left.\begin{array}{l}\mathrm{PaW} 705 \\
\mathrm{PaW} 719\end{array}\right\}$ & $\begin{array}{l}\mathrm{Nah}^{+} 2 \mathrm{MeNah}^{+} \mathrm{Sal}^{+} 4 \mathrm{MeSal}^{+} 5 \mathrm{MeSal}^{+} \\
\operatorname{Trp}^{-} \mathrm{Str}^{r} \text { (group B) }\end{array}$ & $\left\{\begin{array}{l}\text { pWW60-14 } \\
\text { pWW60-22 }\end{array}\right.$ & 2-methylnaphthalene \\
\hline
\end{tabular}

* Phenotype designations: $\mathrm{Nah}^{+}, 2 \mathrm{MeNah}^{+}, \mathrm{Sal}^{+}, 4 \mathrm{MeSal}^{+}, 5 \mathrm{MeSal}^{+}, \mathrm{Mtol}^{+}, \mathrm{Ben}^{+}$and $\mathrm{Cat}^{+}$denote the ability to grow on naphthalene, 2-methylnaphthalene, salicylate, 4-methylsalicylate, 5-methylsalicylate, $m$-toluate, benzoate and catechol, respectively, as sole carbon sources. $\operatorname{Trp}^{-}$, requirement for tryptophan; $\operatorname{Str}^{\mathrm{r}}$, resistance to streptomycin.

$\dagger$ Conjugation (donor $\times$ recipient). 
repeated. The acid ether extracts were combined, dried with anhydrous $\mathrm{Na}_{2} \mathrm{SO}_{4}$, decanted and evaporated to dryness at room temperature. Portions of the residue were dissolved in $0 \cdot 1 \mathrm{M}-\mathrm{NaOH}$ and their UV spectra compared with authentic salicylate $\left(\lambda_{\max }\right.$ at $209 \mathrm{~nm}, 230 \mathrm{~nm}$ and $296 \mathrm{~nm}$ ), 4-methylsalicylate ( $\lambda_{\max }$ at $214 \mathrm{~nm}, 239$ $\mathrm{nm}$ and $296 \mathrm{~nm}$ ) and 5-methylsalicylate $\left(\lambda_{\max }\right.$ at $215 \mathrm{~nm}, 230 \mathrm{~nm}$ and $\left.305 \mathrm{~nm}\right)$. For TLC, portions of the residue were dissolved in ethanol, applied to silica gel plates and chromatographed in one of two solvents: (i) chloroform/ acetic acid $(9: 1, v / v)$ and (ii) benzene/dioxan/acetic acid $(90: 25: 4$, by vol.). All three salicylates cochromatographed in both solvents, with an $R_{F}$ of 0.85 in solvent (i) and an $R_{F}$ of 0.5 in solvent (ii). Trimethylsilyl derivatives for GLC were prepared as follows. The dry residue $(2 \mathrm{mg})$ after acid ether extraction was dissolved in $0.2 \mathrm{ml}$ pyridine, then $0.2 \mathrm{ml} \mathrm{N}, \mathrm{O}$-bis-(trimethylsilyl)trifluoroacetamide was added and the mixture heated at $60^{\circ} \mathrm{C}$ for $30 \mathrm{~min}$. Samples were separated on a $1.5 \mathrm{~m} \times 4 \mathrm{~mm}$ internal diameter silanized glass column packed with $1 \%$ (w/w) OV-17 on Chromasorb G (100 to 120 mesh) in a Pye 104 gas chromatograph fitted with a flame ionization detector. The temperature of the column was increased at a rate of $16^{\circ} \mathrm{C} \min ^{-1}$ from $100{ }^{\circ} \mathrm{C}$ to $300{ }^{\circ} \mathrm{C}$.

\section{RESULTS}

\section{Plasmids in Pseudomonas sp. NCIB 9816}

The fragments obtained after HindIII digestion of plasmid DNA from PGB1 (Pseudomonas sp. NCIB 9816, wild-type) are shown in Table 2. These fragments were shown to derive from two plasmids. Transfer of the IncP9 TOL plasmid pWW0 into PGB1, selecting for growth on the TOL specific growth substrate $m$-toluate (Williams \& Murray, 1974), resulted in transconjugants, all of which had lost the ability to grow on naphthalene. One such transconjugant, PGB2, was cured of the TOL plasmid by growth on benzoate (Williams \& Murray, 1974) to give PGB3. The naphthalene plasmid from PGB1 was isolated by conjugation with a plasmid-free strain $\mathrm{PaW} 340\left(\mathrm{Trp}^{-} \mathrm{Str}^{\mathrm{r}}\right.$ ) as recipient, selecting for growth on naphthalene: PaW701 was one of a very few transconjugants from this mating. Comparison of the HindIII digests of the plasmid DNA from PGB3 and PaW701 with PGB1 (Table 2), shows that the plasmid DNA of PGB1 was resolved as two plasmids: pWW61, an apparently cryptic plasmid of about 60-65 kb (in PGB3) and a naphthalene catabolic plasmid pWW60 (87 kb).

All further studies were carried out on PaW701, the plasmid of which we have called pWW601 to distinguish it from the parent plasmid in PGB1. Plasmid pWW60-1 appears to be identical to pWW60 on digestion with HindIII, BamH1, XhoI and SalI. However EcoRI digests are different. We can detect $11 E c o$ RI fragments of pWW60 whereas there are 15 fragments of pWW60-1; only seven fragments in each appear to correspond. We assume that a number of minor changes in structure, perhaps similar to modification, take place when pWW60 is transferred into PaW340 and that these are only detectable on EcoRI digestion.

The implication that the naphthalene catabolic plasmid is of the P9 incompatibility group from its exclusion by $\mathrm{pWW0}$ was confirmed by the reverse transfer. Plasmid pWW60-1 was transferred from $\mathrm{PaW} 701$ into $\mathrm{PaW} 1$, selecting for transconjugants able to grow on naphthalene $\left(\mathrm{Nah}^{+}\right)$. All had lost the ability to grow on the pWW0 substrate $m$-toluate $\left(\mathrm{Mtol}^{-}\right)$. Examination of the plasmid content of one such transconjugant confirmed that it contained only pWW60-1 and that pWW0 had been eliminated.

\section{Metabolic properties of $\mathrm{PaW701}$}

The activities of some of the relevant enzymes of naphthalene catabolism are shown in Table 3. Both $\mathrm{C} 12 \mathrm{O}$ and MLE were induced by growth on salicylate and naphthalene whereas the meta pathway enzymes $\mathrm{C} 23 \mathrm{O}$, HMSH and HMSD were not significantly induced; $\mathrm{C} 23 \mathrm{O}$ in particular maintained a constant low constitutive level of activity.

Strain PaW701 was unable to grow on 2-methylnaphthalene or on 4- or 5-methylsalicylate $\left(2 \mathrm{MeNah}^{-} 4 \mathrm{MeSal}^{-} 5 \mathrm{MeSal}^{-}\right)$. When it was incubated in medium containing 2-methylnaphthalene, 4-methylsalicylate or 4-methylcatechol, there was little or no growth but the medium gradually changed colour with early accumulation of a yellow compound with a spectrum identical to that of 2-hydroxy-5-methylmuconic semialdehyde, the meta ring fission product of 4methylcatechol (Murray et al., 1972). The medium later turned brown, having an absorbance maximum at $440 \mathrm{~nm}$ which was enhanced in alkali but disappeared in acid. We have not been 


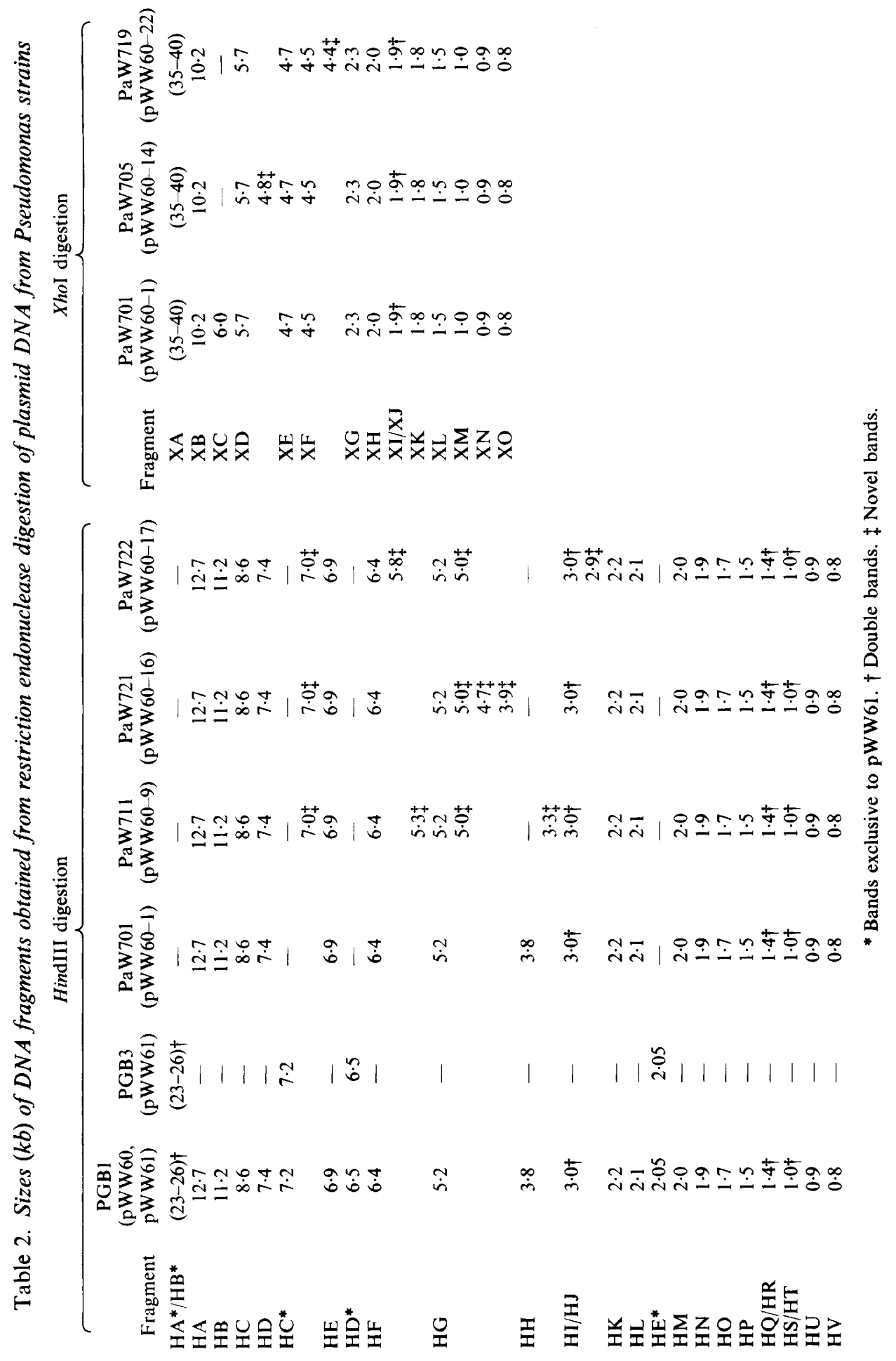


Table 3. Enzyme activities in Pseudomonas strains

\begin{tabular}{|c|c|c|c|c|c|c|c|}
\hline \multirow[b]{2}{*}{ Strain } & \multirow[b]{2}{*}{ Growth substrate } & \multicolumn{6}{|c|}{ Specific activity [nmol $\left.\min ^{-1}(\mathrm{mg} \text { protein })^{-1}\right]$} \\
\hline & & SH & $\mathrm{C} 12 \mathrm{O}$ & MLE & $\mathrm{C} 23 \mathrm{O}$ & HMSD & HMSH \\
\hline PaW701 & $\begin{array}{l}\text { Acetate } \\
\text { Salicylate } \\
\text { Naphthalene }\end{array}$ & $\begin{array}{r}<5 \\
125 \\
11\end{array}$ & $\begin{array}{r}<5 \\
200 \\
54\end{array}$ & $\begin{array}{r}<5 \\
115 \\
85\end{array}$ & $\begin{array}{l}20 \\
37 \\
28\end{array}$ & $\begin{array}{l}3 \\
3 \\
2\end{array}$ & $\begin{array}{r}<1 \\
<1 \\
8\end{array}$ \\
\hline PaW711 & $\begin{array}{l}\text { Acetate } \\
\text { Naphthalene } \\
\text { 2-Methylnaphthalene }\end{array}$ & $\begin{array}{l}<5 \\
<5 \\
<5\end{array}$ & $\begin{array}{l}<5 \\
21 \\
<5\end{array}$ & $\begin{array}{l}<5 \\
<5 \\
<5\end{array}$ & $\begin{array}{l}21 \\
18 \\
13\end{array}$ & $\begin{array}{r}2 \\
<1 \\
<1\end{array}$ & $\begin{array}{r}4 \\
4 \\
<1\end{array}$ \\
\hline $\mathrm{PaW} 705$ & $\begin{array}{l}\text { Acetate } \\
\text { Salicylate } \\
\text { Naphthalene } \\
\text { 2-Methylnaphthalene }\end{array}$ & $\begin{array}{l}<5 \\
\text { ND } \\
\text { ND } \\
\text { ND }\end{array}$ & $\begin{array}{l}<5 \\
<5 \\
<5 \\
<5\end{array}$ & $\begin{array}{l}\text { ND } \\
\text { ND } \\
\text { ND } \\
\text { ND }\end{array}$ & $\begin{array}{r}72 \\
1540 \\
1430 \\
1460\end{array}$ & $\begin{array}{r}7 \\
124 \\
25 \\
30\end{array}$ & $\begin{array}{r}<1 \\
<1 \\
5 \\
4\end{array}$ \\
\hline PaW719 & $\begin{array}{l}\text { Acetate } \\
\text { Salicylate } \\
\text { Naphthalene } \\
\text { 2-Methylnaphthalene }\end{array}$ & $\begin{array}{l}<5 \\
\text { ND } \\
\text { ND } \\
\text { ND }\end{array}$ & $\begin{array}{l}<5 \\
<5 \\
<5 \\
<5\end{array}$ & $\begin{array}{l}\text { ND } \\
\text { ND } \\
\text { ND } \\
\text { ND }\end{array}$ & $\begin{array}{r}160 \\
2560 \\
1460 \\
1070\end{array}$ & $\begin{array}{r}7 \\
180 \\
28 \\
32\end{array}$ & $\begin{array}{r}<1 \\
12 \\
3 \\
3\end{array}$ \\
\hline
\end{tabular}

able to identify the compound responsible but assume that it is formed from 2-hydroxy-5methylmuconic semialdehyde but is not further metabolized.

Mutants of PaW701 appeared spontaneously on 2-methylnaphthalene plates at a frequency of about $10^{-5}$. Fifteen independently isolated mutants were purified and, on the basis of their growth phenotype, were found to fall into two groups. Thirteen mutants (group A) were $\mathrm{Nah}^{+} 2 \mathrm{MeNah}^{+} \mathrm{Sal}^{-} 4 \mathrm{MeSal}^{-} 5 \mathrm{MeSal}^{-}$whereas two mutants (group B) were $\mathrm{Nah}^{+} 2 \mathrm{MeNah}^{+} \mathrm{Sal}^{+} 4 \mathrm{MeSal}^{+} 5 \mathrm{MeSal}^{+}$.

\section{Metabolic properties of group A mutants}

Group A mutants grew only weakly on either naphthalene or 2-methylnaphthalene, both on plates and in liquid culture; with limiting naphthalene only about $30-40 \%$ of the turbidity of the parent PaW701 was obtained. Enzyme assay of one group A mutant, PaW711 (Table 3) showed that neither the ortho pathway enzymes, $\mathrm{C} 12 \mathrm{O}$ and MLE, nor the meta pathway enzymes, $\mathrm{C} 23 \mathrm{O}$, HMSH and HMSD, were induced to any significant degree by growth on naphthalene or 2methylnaphthalene, and no SH activity could be detected under any growth conditions. These results were typical of all the other group A mutants tested.

Culture supernatants of group A strains growing on naphthalene accumulated a compound with a UV spectrum identical to that of salicylate. Acid ether extracts of the supernatant of naphthalene-grown PaW711 contained a UV fluorescent compound which co-chromatographed with authentic salicylic acid on TLC using two different solvents. Further confirmation of the identity of the compound as salicylic acid was obtained by preparing the trimethylsilyl derivative of the acid ether extractable material and running it on GLC with authentic trimethylsilylated salicylic acid. Quantitative estimates of the amount of salicylate present in supernatants, both by direct measurement of their absorbance and by the method of Trinder (1954), indicated that about $60 \%$ of the naphthalene present at the start of the culture was converted to salicylate. This is likely to be a minimum estimate because of the difficulty of estimating whether there had been incomplete metabolism of the naphthalene or whether there had been losses due to its volatilization during growth.

When PaW711 was grown on 2-methylnaphthalene, 4-methylsalicylate accumulated in the medium; this was distinguished from salicylate by GLC of its trimethylsilyl derivative, and from 5-methylsalicylate by its UV spectrum.

\section{Metabolic properties of group B mutants}

Both strains, $\mathrm{PaW} 705$ and $\mathrm{PaW719}$, grew vigorously on naphthalene, 2-methylnaphthalene, salicylate and 4- and 5-methylsalicylate. Enzyme assay (Table 3) showed that the meta pathway 
enzymes $\mathrm{C} 23 \mathrm{O}$ and HMSD were induced to high levels, but that HMSH was not significantly induced. SH activity could not be assayed because the rapid production of 2-hydroxymuconic semialdehyde (from the action of the high levels of $\mathrm{C} 23 \mathrm{O}$ on catechol, the product of $\mathrm{SH}$ ) interfered with the spectrophotometric assay for $\mathrm{SH}$. No $\mathrm{C} 12 \mathrm{O}$ activity could be detected, although it is possible that it was present in low levels but that these could not be measured in the presence of the high specific activity of $\mathrm{C} 23 \mathrm{O}$ competing for the same substrate.

\section{Plasmid structure in group A mutants}

The plasmid DNA of all group A mutants was isolated and digested with HindIII and XhoI restriction endonucleases; the fragments after HindIII digestion of three representative plasmids are shown in Table 2. Compared with the parental plasmid pWW60-1, all the mutant plasmids had lost a single band, $\mathrm{HH}(3.8 \mathrm{~kb})$ in the HindIII digests, and XC $(6.0 \mathrm{~kb})$ in the $X h o \mathrm{I}$ digests. In their place all had acquired four new HindIII bands and three new XhoI bands; the total additional DNA in all plasmids was $16.7 \mathrm{~kb}$. Each plasmid had in common two new $H$ indIII bands of 7.0 and $5.0 \mathrm{~kb}$, the other two novel bands being different for each. In the XhoI digests one novel band $(2.7 \mathrm{~kb})$ was common to all mutants and of the other two, one was always large $(15 \cdot 5-17.5 \mathrm{~kb})$ and one small $(2 \cdot 0-4 \cdot 0 \mathrm{~kb})$ (results not shown).

These results are consistent with the insertion of a $17 \mathrm{~kb}$ DNA fragment containing three HindIII and two XhoI sites into the region of the plasmid common to fragments $\mathrm{HH}$ and $\mathrm{XC}$. The exact site of insertion obviously differs from mutant to mutant since the flanking insertplasmid hybrid fragments are of varying sizes.

\section{Plasmid structure in group B mutants}

The plasmids from both group B mutants were digested with XhoI (Table 2) and HindIII. Plasmid pWW60-22 had lost fragment XC $(6.0 \mathrm{~kb})$ and acquired a novel $4.4 \mathrm{~kb}$ fragment, with net loss of $1.6 \mathrm{~kb}$. From the HindIII digest it had lost fragment $\mathrm{HH}(3.8 \mathrm{~kb})$ and one element from each of the double bands HQ/HR $(1.4 \mathrm{~kb})$ and HS/HT $(1.0 \mathrm{~kb})$, and acquired a novel band of $4.5 \mathrm{~kb}$, with net loss of $1.7 \mathrm{~kb}$. The other plasmid, pWW60-14 had also lost fragment XC which was replaced by a $4.8 \mathrm{~kb}$ band, with net loss of $1.2 \mathrm{~kb}$. From the HindIII digest it had lost fragment $\mathrm{HH}$ and one element from the double HS/HT band and acquired a novel $3.5 \mathrm{~kb}$ band, with net loss of $1.3 \mathrm{~kb}$.

The plasmids in these two mutants each appear to have suffered a deletion of DNA (about 1.6 $\mathrm{kb}$ in $\mathrm{pWW} 60-22$ and about $1.2 \mathrm{~kb}$ in pWW60-14) in the region corresponding to fragment $\mathrm{XC}$ and the end of fragment $\mathrm{HH}$ running into $\mathrm{HQ}$ and $\mathrm{HS}$.

\section{Location of the ortho and meta pathway genes}

It is possible that the two catechol-degrading pathways, the ortho pathway in PaW701, and the meta pathway in PaW719, a group B mutant, were determined either by plasmids in those strains or by the host chromosomes. In order to distinguish between these possibilities, both strains were used as donors in matings with two plasmid-free recipients, selecting for $\mathrm{Nah}^{+}$. Strain PaW85 is derived from PaWl by loss of pWW0 (Bayley et al., 1977) and has a fully functional chromosomal ortho pathway. Strain PaW11 is a plasmid-free mutant also derived from $\mathrm{PaW} 1$, which cannot grow on benzoate or catechol and therefore has a non-functional ortho pathway.

Strain PaW719 transferred its plasmid (pWW60-22) to both PaW85 and PaW11 to produce transconjugants with the same catabolic phenotype as itself. The plasmids in the transconjugants were identical to that in the donor. Thus, the meta pathway is plasmid coded and a functional chromosomal ortho pathway is not required.

Strain PaW701 transferred pWW60-1 to PaW85, to produce transconjugants with identical catabolic phenotype and plasmid content as the donor. However, only pinprick transconjugant colonies were found when PaW11 was the recipient, although analysis of their plasmid DNA showed it to be identical to pWW60-1. We therefore conclude that full expression of the $\mathrm{Nah}^{+}$ phenotype in $\mathrm{PaW} 701$ and its transconjugants requires a functional chromosomal ortho pathway in addition to the plasmid genes for conversion of the naphthalene to catechol. The ability of 
transconjugants of PaW11 containing pWW60-1 to produce even minute colonies on naphthalene must result from the pyruvate released from oxidation of the first ring. This idea is given added weight by their total inability to grow on salicylate.

\section{DISCUSSION}

Strain PaW701 contains an IncP9 plasmid, pWW60-1, derived by conjugation from PGB1 (NCIB 9816) which carries genes for the catabolism of naphthalene. In PaW701 the naphthalene appears to be metabolized through salicylate, catechol and the ortho pathway. The evidence for this is as follows. (a) C12O and MLE, the first two enzymes of the ortho sequence, are induced by growth on naphthalene whereas the corresponding meta pathway enzymes, $\mathrm{C} 23 \mathrm{O}, \mathrm{HMSH}$ and HMSD, although detectable, are at low levels and are not significantly induced. (b) PaW701 does not grow on 2-methylnaphthalene, contrary to what might be expected were it a strain with a functional meta pathway, given the well documented nonspecificity of that pathway (Bayly \& Dagley, 1969; Murray et al., 1972): 2-methylnaphthalene and 4-methylsalicylate are only partially metabolized by PaW701, through 4-methylcatechol and its meta ring fission product to an unidentified brown product which is not metabolized further, indicating that the meta pathway is not completely functional. Strain PaW701 can however acquire the ability to grow on 2-methylnaphthalene by mutation in one of two ways.

In all the 13 independently isolated group A mutants, a large insertion of about $17 \mathrm{~kb}$ appears in the same region of the plasmid ( $\mathrm{HH}$ and $\mathrm{XC}$ ). The evidence from the enzyme assays, the almost stoichiometric accumulation of salicylate in the medium and the loss of the mutants' ability to grow on salicylate, shows that their SH is not active, presumably as a direct result of the insertion. Their ability to grow on naphthalene must be due to their utilization of the three carbon atoms released as pyruvate, resulting from cleavage of the first ring (Davies \& Evans, 1964); this accounts for their poorer growth yield. We cannot say whether the loss of SH activity is due to insertional inactivation of its structural gene or of a regulatory gene essential for its expression.

Depending on which carbon atoms are attacked by the initial oxygenase, it is possible to envisage a number of different metabolites of 2-methylnaphthalene at the level of salicylate. However, the accumulation of 4-methylsalicylate from 2-methylnaphthalene in almost stoichiometric quantities by the group A mutants shows that this initial attack must be on carbon atoms 7 and 8 , as described by Rogoff $\&$ Wender (1959). The mutants must also use the pyruvate from oxidation of the unsubstituted ring of 2-methylnaphthalene as carbon for growth. We assume that the reason why the parent strain PaW701 does not grow on the same pyruvate when it appears to be able to metabolize 2-methylnaphthalene past the 4-methylsalicylate stage is because some product of its partial metabolism, probably the brown unidentified product accumulated in the medium, is toxic; only mutational loss of the SH activity will stop its formation and thus allow utilization of the three available carbons.

The $17 \mathrm{~kb}$ fragment of DNA, which is found as an insert in the plasmids of the group A mutants, behaves as a transposon. In other derivatives of $\mathrm{PaW} 701$ we have found it present in different fragments of $\mathrm{pWW60-1}$ without any effect on the host phenotype, and we have also found it as an insertion in other catabolic and $\mathrm{R}$ plasmids which have been transferred into $\mathrm{PaW} 340$. Preliminary evidence from Southern blot hybridization and from mapping the cutting sites of a number of restriction enzymes has led us to identify tentatively the $17 \mathrm{~kb}$ region as a residue of DNA in the chromosome of PaW340 left from the TOL plasmid pWW0 which was originally present in P. putida mt-2 (PaW1), the parental strain from which PaW340 was derived. The same $17 \mathrm{~kb}$ has also been described as a residue of pWW0 after its transfer and subsequent structural alteration in a chlorobenzoate-degrading Pseudomonas sp. (Jeenes \& Williams, 1982). However, it should be stressed that none of the TOL catabolic genes appear to be located on this region (Jeenes \& Williams, 1982), and that the changes in catabolic phenotype found in PaW701 and its derivatives therefore cannot be attributed to the introduction of novel catabolic genes originally present on another plasmid. We believe that the effect of the $17 \mathrm{~kb}$ transposon in the group A mutants is solely that of insertional mutagenesis. 
In the group B mutants, a deletion in a closely linked region of pWW60-1 DNA allows high levels of induction of the meta pathway enzymes. Not only is good growth maintained on naphthalene and salicylate, but these mutants have acquired the ability to grow on 2methylnaphthalene and both 4- and 5-methylsalicylates. This is due to the relaxed specificity of the meta pathway enzymes allowing complete metabolism of methylcatechols, as compared with the specificity of the ortho pathway, capable of metabolizing only catechol itself (Feist \& Hegeman, 1969). The low levels of HMSH even in PaW719, where C23O and HMSD are induced, are consistent with the observation that the hydrolase branch of the meta pathway is of no metabolic significance in strain NCIB 9816 (Catterall et al., 1971).

A curious feature of pWW60-1 is that it apparently carries the meta pathway genes in a form normally unexpressed, and that it requires a functional chromosomal ortho pathway for complete metabolism of naphthalene. Only when it acquires a small deletion, as in the group B mutants, is the full catabolic potential of the plasmid determined genes made available to the host bacterium by allowing the meta pathway to be utilized. It is possible that $\mathrm{pWW60-1}$ is itself derived from a plasmid which has acquired an insertion sequence blocking expression of its meta pathway enzymes. Normally this might be expected to destroy any selective advantage conferred on the host by the plasmid, and thus counterselect against its continued maintenance in the population. However, the nature of the block is such that $\mathrm{pWW60-1}$ can still function as a naphthalene plasmid in hosts carrying a functional ortho pathway, a virtually ubiquitous feature of $P$. putida strains.

The ease with which changes in plasmid structure which have a drastic effect on the catabolic phenotype occur in these strains may well explain the conflicting reports on the naphthalene catabolism of Pseudomonas NCIB 9816. Strain PaW701 behaves very similarly to the clone of this strain described by Barnsley (1976) in appearing to use the ortho pathway, and yet expressing low constitutive levels of $\mathrm{C} 23 \mathrm{O}$. On the other hand, the group B mutants resemble the clone of NCIB 9816 (Pseudomonas $\mathrm{P}_{\mathrm{G}}$ ) as described by Williams et al. (1975) which used the meta pathway and grew on 2-methylnaphthalene. It is easy to see how biochemical and genetic variants of a single original clone can arise in different laboratories if they are subjected to selective pressures which so readily result in irreversible changes in genotype.

Note added in proof. After preparation of this manuscript, a paper by M. A. Connors \& E. A. Barnsley [Journal of Bacteriology (1982), 149, 1096-1101] has confirmed the presence of two plasmids in NCIB 9816, and the involvement of the larger in naphthalene catabolism.

We would like to thank Dr John Gorham for help with GLC and Linda Gibb for her technical help. P. A.C. is the holder of a University of Wales Research Fellowship. This work was funded in part by a Research Grant from Exxon Research and Engineering Company, Linden, N.J., U.S.A.

\section{REFERENCES}

BARNSLeY, E. A. (1976). Role and regulation of the ortho and meta pathways of catechol metabolism in pseudomonads metabolising naphthalene and salicylate. Journal of Bacteriology 125, 404-408.

Bayley, S. A., Duggleby, C. J., Worsey, M. J., Williams, P. A., HaRdy, K. G. \& BRodA, P. (1977). Two modes of loss of the TOL function from Pseudomonas putida mt-2. Molecular and General Genetics 154, 203-204.

BAYLY, R. C. \& Dagley, S. (1969). Oxoenoic acids as metabolites in the bacterial degradation of catechols. Biochemical Journal 111, 303-307.

Boronin, A. M., Kochetov, V. V., Starovortov, I. I. \& SkrYabIN, G. K. (1977). Plasmids pBS2 and pBS3, controlling the oxidation of naphthalene in bacteria of the genus Pseudomonas. Doklady Akademii nauk SSSR 237, 1205-1208.

Boronin, A. M., KochetKov, V. V. \& SKryabin, G. K. (1980). Incompatibility groups of naphthalene degradative plasmids in Pseudomonas. FEMS Microbiology Letters 7, 249-252.

Catterall, F. A., Sala-Trepat, J. M. \& Williams, P. A. (1971). The coexistence of two pathways for the metabolism of 2-hydroxymuconic semialdehyde in a naphthalene-grown pseudomonad. Biochemical and Biophysical Research Communications 43, 463-469.

Davies, J. I. \& Evans, W. C. (1964). Oxidative metabolism of naphthalene by soil pseudomonads. Biochemical Journal 91, 251-261.

Downing, R. G. \& BRoda, P. (1980). A cleavage map of the TOL plasmid of Pseudomonas putida mt-2. Molecular and General Genetics 177, 189-191.

Dunn, N. W. \& Gunsalus, I. C. (1973). Transmissible plasmid coding early enzymes of naphthalene oxidation in Pseudomonas putida. Journal of Bacteriology 114, 974-979.

Feist, C. F. \& Hegeman, G. D. (1969). Phenol and benzoate metabolism by Pseudomonas putida: regu- 
lation of tangential pathways. Journal of Bacteriology 100, 869-877.

Hayaishi, O., Katagiri, N. \& RothberG, A. (1957). Studies on oxygenases: pyrocatechase. Journal of Biological Chemistry 229, 905-920.

JeEnes, D. J. \& Williams, P. A. (1982). Excision and integration of degradative pathway genes from TOL plasmid pWW0. Journal of Bacteriology 150, 188194.

Jeenes, D. J., Reineke, W., Knackmuss, H-J. \& WILLIAMS, P. A. (1982). The TOL plasmid pWW0 in constructed halobenzoate degrading Pseudomonas strains: enzyme regulation and DNA structure. Journal of Bacteriology 150, 180-187.

Murray, K., Duggleby, C. J., Sala-Trepat, J. M. \& Williams, P. A. (1972). The metabolism of benzoate and methyl benzoates via the meta cleavage pathway by Pseudomonas arvilla mt-2. European Journal of Biochemistry 28, 301-310.

ORNSTON, L. N. (1966). The conversion of catechol and protocatechuate to $\beta$-ketoadipate by Pseudomonas putida. III. Enzymes of the catechol pathway. Journal of Biological Chemistry 241, 3795-3799.

Pickup, R. \& Williams, P. A. (1982). Spontaneous deletions in the TOL plasmid pWW20 which give rise to the B3 regulatory mutants. Journal of General Microbiology 128, 1385-1390.

RogofF, M. H. \& Wender, I. (1959). Methylnaphtha- lene oxidations by pseudomonads. Journal of Bacteriology 77, 783-788.

Sala-Trepat, J. M., Murray, K. \& Williams, P. A. (1972). The metabolic divergence in the meta cleavage of catechols by Pseudomonas putida NCIB 10015. Physiological significance and evolutionary implications. European Journal of Biochemistry 28, 347-356.

TRINDER, P. (1954). Rapid determination of salicylate in biological fluids. Biochemical Journal 57, 301-303.

WheAtCroft, R. \& Williams, P. A. (1981). Rapid methods for the study of both stable and unstable plasmids in Pseudomonas. Journal of General Microbiology 124, 433-437.

Williams, P. A. \& MURRay, K. (1974). Metabolism of benzoate and the methylbenzoates by Pseudomonas putida (arvilla) $\mathrm{mt}-2$ : evidence for the existence of a TOL plasmid. Journal of Bacteriology 120, 416-423. Williams, P. A., Catterall, F. A. \& Murray, K. (1975). Metabolism of naphthalene, salicylate and benzoate by Pseudomonas $\mathrm{P}_{\mathrm{G}}$ : regulation of tangential pathways. Journal of Bacteriology 124, 679 685.

Yamamoto, S., Katagiri, H., Maeno, H. \& HaYaishi, O. (1965). Salicylate hydroxylase, a monooxygenase requiring flavin adenine dinucleotide. I. Purification and general properties. Journal of Biological Chemistry 240, 3408-3413. 